\title{
THE MAGNIFICENT FIVE OF THE CATALAN FAR WEST
}

\author{
Sergio Canavati, Sonoma State University, United States \\ Daniel Rajmil, Universität de Barcelona \\ Agusti Casas, Universität de Barcelona \\ Marieshka Barton, Sonoma State University, United States
}

"Catalans can make bread from stones, but the Prioratins can also make wine from stones." --An old proverb from El Priorat, Western Catalonia

$\mathrm{I}$ n the illuminated ruins of the 12th century Scala Dei Monastery, the men and women of Priorat's original wine commune gathered in the autumn of 2014 to pay homage and celebrate their achievements. The Magnificent Five, as they were affectionately called amongst Spaniards, celebrated the 25th anniversary ${ }^{\mathrm{i}}$ of their first successes ${ }^{\mathrm{ii}}$. Ten bottles of Priorat wine were symbolically opened as they toasted the past and talked about the future. Despite 25 years of brand building, the wineries still faced challenges in the global market, a market with considerably more competition than in the late 1980s. Even in the geographically limited region of Priorat, nearly 200 wineries competed in 2014 compared to the original four wineries in 1986. The band of friends had succeeded this far and toasted to the exciting and challenging futures ahead of them.

A few days after the party, Francesc Capafons-Osso, a veteran winemaker who had taken the role of the group's father figure, summoned the Magnificent Five winemakers and proposed a project that would gather their experience and professionalism to produce a new, competitive product. It was an ambitious proposal considering that Priorat was a micro-production region where steep vineyards on craggy mountain slopes produced unique flavors at scare yields. Its rugged terrain limited harvests to less than 800 kilos of grapes per acre compared to the average 4,000 kilos from industrialized wine-growing zones. Furthermore, the Magnificent Five were no longer as close as they had been in the early days when they were young farmers working as a commune. Could the "Magnificent Five" band together to launch a unified brand? Could these high-end winemakers from remote Priorat leverage their individual brands and historical bond to create a synergy? To create a wine that was the best of each of them? 


\section{BACKGROUND OF EL PRIORAT AND THE MAGNIFICENT FIVE}

In the mid-1980s, a group of adventurers passionate about viticulture staked out a corner of Spain's Western Catalonia region in remote El Priorat to produce wines. The pioneers, René Barbier of Clos Mogador and Álvaro Palacios of Clos Dofí, blazed the path and were soon followed by Daphne Gloriann of Clos Erasmus, Carlos Pastrana of Clos de l'Obac, and José Luis Pérez of Clos Martinet. These five wine entrepreneurs would later be dubbed the "Magnificent Five," partly in recognition of their pioneering work and leadership to revive El Priorat's historical wine industry. ${ }^{\text {iii }}$ Priorat's regional success was predicated on three factors: 1) the dry climate and poor-nutrient Llicorella soil that drove the vines deep into the earth, resulting in unique flavors, 2) the ancient vineyards that had been continuously tended since the 1200s by monks and farmers, and 3) the ingenuity of the five newcomers.

The Magnificent Five helped resurrect Priorat's long wine tradition that nearly went extinct from the phylloxera blight followed by the exodus of farmers seeking work elsewhere. The newcomers were able to start their ventures without substantial capital investments due to the low cost of vineyards in the depopulated and economically decimated Priorat. However, the Magnificent Five did not do it entirely alone; they used some availed themselves of the traditional winegrowers in the region who remained farming the old vines despite economic hardships. The newcomers negotiated with the local-agricultural cooperatives to supply raw and complementary products, which helped re-stimulate the local economy. The bold, young farmers invested everything they had and staked their claim in the landscape of the dry Sierra del Montsant Mountains dotted with monasteries and vines.

The venture was too arduous alone, but as a team they found success and overcame the hardships of the remote Priorat and collaborated on the possibility of a viable wine industry in the region. Each professional contributed knowledge, previous experience, and resources to the project. Rene had knowledge of the industry and was an expert winemaker, and Palacios had experience in international markets and helped to increase sales and the growth of Priorat international markets. Rene and Alvaro knew how to prospect agriculture lands and had technical expertise in wine production. They recognized the potential of Priorat wine and were convinced that it could become a high-quality wine region. At the same time, José Luis brought the necessary business expertise to increase production quality, and Carlos Pastrana had the financial and management experience that allowed them to structure a company. Alvaro and Glorian handled market knowledge and international sales. For the first three years of the adventure (1989-1991), they produced one wine marketed under five different labels. Glorian of Clos Erasmus reflected on the early days, "It was like a commune"iv . And, Alvaro remembered that "When we started in the 80s, nobody in the US knew where Priorat was; we had to go with a map and show them. There was no internet!” 
By the mid-1990s, Priorat had gained international recognition and was in demand, challenging the Magnificent Five to develop new capabilities and enter new markets with their small production, sense of place wines. Exporting their wines to far off destinations was previously unexploited. All the players said, "Before 1989, the protagonists of wine abroad were in Europe, everyone knew that it could be exported to UK, France, Italy ... but going to the USA was unthinkable!" Alvaro added, "We were newbies, and everything changed when someone said we had the best wine in the world ... from a corner of the country that nobody knew”vi.

The turn of the twentieth century was an exciting growth phase for Priorat wines. In December 2000, the Priorat region obtained the prestigious Denomination de Origen Calificada (DOCa) certification that recognized the region's high-end wines and acted as a control mechanism to monitor and preserve the region's quality production. Glorian also helped further establish Priorat's notoriety as her 2004 Clos Erasmus was the first Catalan wine to receive a perfect 100point score from Parker setting a trend of several notable Parker scores for Priorat's Magnificent Five wineries ${ }^{\text {vii }}$. See Exhibit 1 and Exhibit 2 for a timeline of events and accolades.

\section{Exhibit 1}

Timeline of the transformation of the Priorat region at the turn of the century

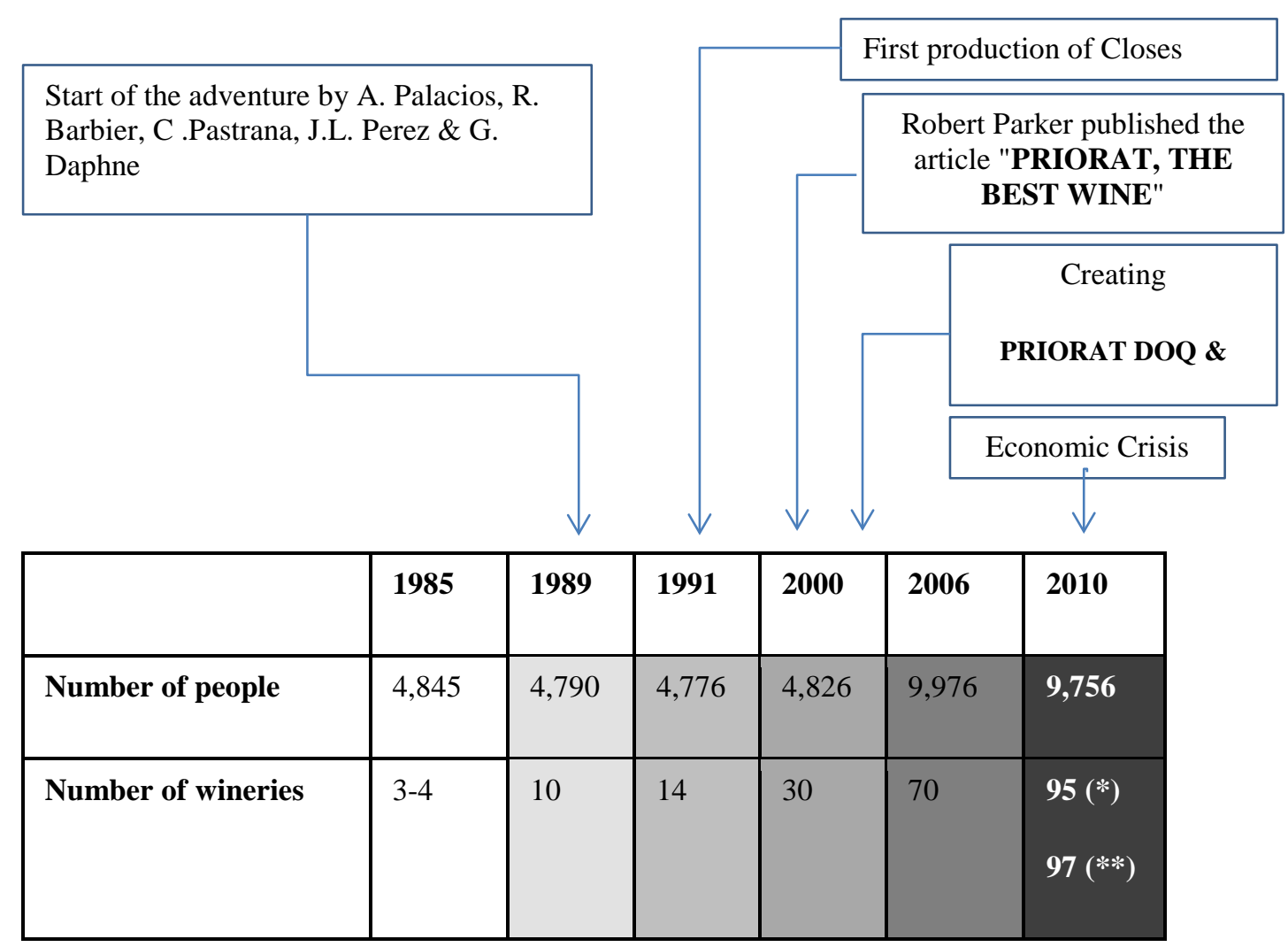

Source: Author's elaboration based on statistics from DOQ Priorat and DO Montsant councils. ${ }^{1}$ 
Exhibit 2

Parker Scores for Select “Magnificent Five” Wines, 2007 - 2010

\begin{tabular}{|c|c|c|c|c|}
\hline & Parke & Points & & \\
\hline Wineries & 2007 & 2008 & 2009 & 2010 \\
\hline Clos Erasmus 2003, Clos Erasmus & 99 & & & \\
\hline Clos Erasmus 2004, Clos Erasmus & 100 & & & \\
\hline Clos Erasmus 2005, Clos i Terrasses & & 100 & & \\
\hline Clos Erasmus 2006, Clos i Terrasses & & & 97 & \\
\hline Clos Erasmus 2007, Clos i Terrasses & & & & 98 \\
\hline \multicolumn{5}{|l|}{ Clos Erasmus 2013, Clos i Terrasses } \\
\hline L’Ermita 2004, Bodegas Álvaro Palacios & 98 & & & \\
\hline L'Ermita 2005, Bodegas Alvaro Palacios & & 98 & & \\
\hline Clos Mogador 2005, Bodegas Clos Mogador & & 98 & & \\
\hline
\end{tabular}

Source: Best Spanish Wines (2017); Catalunya Wine (2014). ${ }^{\text {viii }}$

Given that the international market had enough difficulties in the 90's due to the lack of knowledge of the product (by the market), the 5 magnificent protagonists of this story, realized that the international market was possible in the 90s mainly for two reasons:

1) Due to the impact of an unknown product and,

2) For the commercial link that was subsequently established with USA and Switzerland for commercial / professional reasons of some of the protagonists.

From the 1980s to the mid-2000s, the global wine market experienced radical transformation, especially due to the emergence of good products from the New World and the consolidation of future emerging markets. All this has meant that with small productions, as in the Priorat area, it was essential to prioritize the internal market and consolidate the brand before venturing overseas. However, Priorat wine producers remained alert so as not to lose opportunities to export if the opportunity presented itself. 
The rising tide of Priorat changed direction for the worse when the global economic crisis of 2008 and the ensuing economic contraction devastated the luxury wine segment and Priorat's wine industry. The domestic and export markets collapsed as the business to consumer (B2C) and business to business (B2B) channels shrunk. Limited domestic orders were further reduced, and export orders of pallets were reduced to boxes or even loose units.

\section{THE NEED FOR PARTNERSHIP AND STRATEGY}

At the end of October 2014, Francesc Capafons-Ossó, a well-respected local wine industry leader, proposed a meeting to discuss a possible collaboration. However, there were difficulties in reaching a consensus on the agenda for that meeting. After weeks of uncertainty, the five producers met in early December 2014 at Clos Figueres, home of Christopher Cannan, oenologist and one of the region's leading experts in wine distribution. "We decided by consensus that Christopher would be the project manager because of his leadership and respect that inspired the five of us," recalled Francesc Capafons-Ossó. The first meeting was casual, in the fireplace of the house and Christopher Cannan took the initiative to moderate the meeting.

\section{Product style and fruit sourcing}

They wanted to market a profitable wine with personality and identity from the Priorat area that could compete with the conglomerates, but not devalue the Priorat brand. After the deliberations, they decided on a mixture combination. See Exhibit 3 below.

Exhibit 3. The Magnificent Five’s Proprietary Wine Blend

\begin{tabular}{|c|c|c|}
\hline $\mathbf{\%}$ & Variety & Attributes \\
\hline 10 & Syrah & Aroma \\
\hline 70 & Garnacha & Young fruit \\
\hline 6 & Carignan & Rustic fruit \\
\hline 4 & Cabernet Sauvignon & Structure \\
\hline
\end{tabular}

Source: Authors’ own elaboration based on interviews with the main characters.

\section{Investment and risk}

The participation percentages in the investment were also agreed upon. A system of contributions of providing funds between five parts proportional to their interests and infrastructures was used: (30\% Rene, 24\% Alvaro, 21\% Francesc, 16\% Jose Luis and Glorian 9\% remaining) to receive benefits in the same proportion. 
They agreed that the wine should rest for six months in French oak barrels and finish in American oak. However, five issues remained controversial:

- Should the association of producers be headquartered in one fixed location (Christopher Canaan offered his estate as a permanent headquarters) or should the headquarters location be rotated among all members of the new initiative?

- Should cheaper Rumanian barrels be considered instead of the more expensive French Oak barrels?

- Should production denomination be DOQ Priorat or DO Montsant?

- If two partners (including Christopher Cannan) in the proposed joint venture who are not part of the original Magnificent Five group should be allowed to join the Magnificent Five?

- If new product should be aimed towards the foreign market or if it was better to test it for a couple of seasons in the domestic market and depending on the outcome a decision could be made regarding exporting. Moreover, should expensive marketing experts from outside the Priorat be brought in to train marketing personnel in more state-of-the-art marketing practices?

Seeing that there was no agreement in the previous controversies, Christopher Canaan proceeded to carry out a vote where it was explicit who wanted "internal or external market" and "which DO". In the vote it was clearly in favor of using the Montsant DO and that it would be focused on the internal market.

After one month, the first formal meeting was held to finalize the collaborative project. See Exhibit 4 for a list of meeting attendees.

Exhibit 4

Stakeholders Present at the New Product Development Meeting

\begin{tabular}{|c|c|}
\hline Stakeholder & Winery \\
\hline$[$ Álvaro] Palacios & Finca Dofí, l’Ermita \\
\hline$[$ Francesc] Capafons-Ossó & Mas de Masos \\
\hline$[$ Glorian] Daphne & Clos Erasmus \\
\hline$[$ Josep Luis] Pérez & Clos Martinet \\
\hline$[$ René $]$ Barbier & Clos Mogador \\
\hline$[$ Christopher $]$ Cannan & Clos Figueres \\
\hline
\end{tabular}

Source: Authors’ own elaboration. 
Topic: Collaborative project to produce a new product from El Priorat area. Note:

Resolution: Take the DO Montsant product and focus the new product exclusively on the local market.

All assembled, and Christopher took the floor:

Christopher: “I hope you have reflected on the open topics, who wants to speak first?'

René: "Taking advantage of the fact that we will soon have the annual information of the area, we would do well to take the" temperature "of the exports and see the surplus in the area to decide if we chose the DOQ Priorat with the best scores and notoriety of Parker but with little supply or DO Montsant that is not known outside of Spain but with a surplus of production.”

Christopher: "What do you think of others?"

Álvaro: "I think we all agree that this adventure is less risky if we do it with DO Montsant, besides the varieties of Grenache and Carignan, are having a great boost.

Francesc: "We cannot legally use the Priorat name without the permission of the DOQ Council, which is at $100 \%$ performance."

Francesc: "The DO Montsant allows us to compete with prices and place the product in specialized boutiques, which are gradually establishing themselves in urban areas such as Barcelona, Madrid and other capitals.”

José Luis: "This year the extension permits of the DOQ have been completely stopped because the area is a UNESCO World Heritage candidate, this allows more DO Montsant production margin. I would be in favor of taking him throughout Spain.”

René: "In my opinion, I would start in Catalonia, we are living a real splendor in the city of Barcelona and its surroundings that represents almost $80 \%$ of historical sales. You have to consolidate."

Glorian: "I cannot participate in the production process because I only have vineyards from this DO, my function will be to build a marketing plan and invest heavily on its promotion. I need to know if you like to go with the exclusivity of gourmet wines or you could Access the prestigious HORECA.” 
Álvaro: "I want to remember that conception should not be reoriented towards quality, because this is already supposed, we must reorient ourselves towards the personality of the product with respect to its origins.”

René: "This does not answer the question of Glorian, I would start with the specialized boutiques and leave the HORECA channel for later, we are not specialists in "maridar" (food pairing) we are specialists in elaborating."

After several rounds of questions, Christopher decided to postpone this point for later. He discovered that there were discrepancies. He decided to start a round of proposals related to external or internal marketing. I wanted to know your opinions.

Francesc: "I believe that the HORECA market, with our new exclusive product, depends on the prescriber, distributor ... we must dedicate ourselves to the elaboration and let the professionals do their work until the point of sale, which they decide.”

Glorian: "I have been placing my products especially in the USA and Switzerland, these markets I have controlled with high expectations of expansion. I do not use these parameters, I have to develop a very different marketing plan because the intermediary agents are very different.”

Álvaro: "We are in favor of maintaining a high price, precisely to support the concept of personality that we want. It is not about selling more, but better."

José Luis: "I am in favor of investing in a high-quality product and I hope that the market moves slowly, we must explore the market surgically, first, the domestic environment next and gradually expand into the appropriate environments of the high wine culture.”

René: "We must be prepared for the competition, we have competitors very close to the very powerful, who in addition to making large quantities of products with great acceptance, can do a lot of damage with products of exclusive format because they have many resources. They will not stay with their arms crossed."

Álvaro: "We could divide the new product into two percentages, for example 70\% in boutiques gourmet and the rest in the external channel HORECA to see its impact."

Francesc: “That's even worse, it involves ad hoc promotions that make the price more expensive.”

Jose Luis: "I would be in favor of making a step aside and let the youth who have a more realistic vision of the market decide." (The daughter of José Luis and de Rene are married and have their own winery) 
This last intervention provoked protests from Alvaro and Glorian who claimed the spirit of the Five Magnificent and not of their descendants. Christopher then intervened saying that an agreement had been signed and the signatories were now responsible for the formal decisions.

After more than an hour, the project coordinator asked participants questions related to infrastructure, storage, processing, control, distribution, labeling, price, promotion, etc. The reaction was instantaneous, a tumult was formed where the "offers" intermingled. Palacios offered a new silo of the four that were just being built, Francesc, proposed several acres of Garnacha and Syrah vines of very good quality. José Luis promised to separate six percent of Carignan from a historic vineyard he owned and Rene the four percent of Cabernet Sauvignon that was missing. Glorian committed with Palacios to present various marketing plans for their expertise within the agreed deadlines

Christopher closed the meeting with a bittersweet feeling. On the one hand, he knew that he had to personally resolve (face to face) the open problems and achieve specific commitments that he later took to the forum of the collective meeting. On the other hand, he was satisfied because he understood that when the problems of distribution channels and resolved, the project would take off. Immediately he remembered an old Catalan proverb that was told in the late 1980s: "the Prioratins know how to make wine from stones"

Finally, the expected moment arrived; Christopher was consulting individually each of the Magnificent Five and, with great skill of leadership, he convinced each person individually to agree to his new product development plan. He consulted public data and contrasted it with private and collective interests and convened the final meeting. Exhibit 5 below shows the total domestic and foreign wine sales of Priorat wineries. Exhibit 6 below graphs yearly sales of Priorat wineries in the foreign and domestic markets. 
Exhibit 5

DOQ PRIORAT Domestic and Foreign Wine Sales Table (€ millions), 2005/2013

\begin{tabular}{|c|c|c|c|c|c|c|}
\hline Year & $\begin{array}{c}\text { Domestic } \\
\text { Market }\end{array}$ & $\begin{array}{c}\text { Growth } \\
\text { Rate \% }\end{array}$ & Foreign Market & $\begin{array}{c}\text { Growth } \\
\text { Rate \% }\end{array}$ & $\begin{array}{c}\text { Total Sales } \\
\text { Rate \% }\end{array}$ \\
\hline $\mathbf{2 0 0 5}$ & $€ 940,597$ & & $€ 756,019$ & & $€ 1,696,616$ & $€ 2,930,181$ \\
\hline $\mathbf{2 0 1 0}$ & $€ 1,494,048$ & $59 \%$ & $€ 1,436,133$ & $90 \%$ & $73 \%$ \\
\hline $\mathbf{2 0 1 1}$ & $€ 1,925,889$ & $29 \%$ & $€ 1,857,805$ & $29 \%$ & $€ 3,783,694$ & $29 \%$ \\
\hline $\mathbf{2 0 1 2}$ & $€ 2,079,007$ & $8 \%$ & $€ 2,079,179$ & $12 \%$ & $€ 4,158,186$ & $10 \%$ \\
\hline $\mathbf{2 0 1 3}$ & $€ 1,915,553$ & $-8 \%$ & $€ 1,997,126$ & $-4 \%$ & $€ 3,912,679$ & $-6 \%$ \\
\hline AVERAGE & & $\mathbf{2 2 \%}$ & & $\mathbf{3 2 \%}$ & & $\mathbf{2 6 \%}$ \\
\hline
\end{tabular}

Source: Authors calculations based on statistics provided by Generalitat de Catalunya, DOQ Priorat Council, and DO Montsant Council ${ }^{\mathrm{ix}}$.

\section{Exhibit 6}

DOQ PRIORAT Domestic and Foreign Wine Sales Graph (€millions), 2005/2012

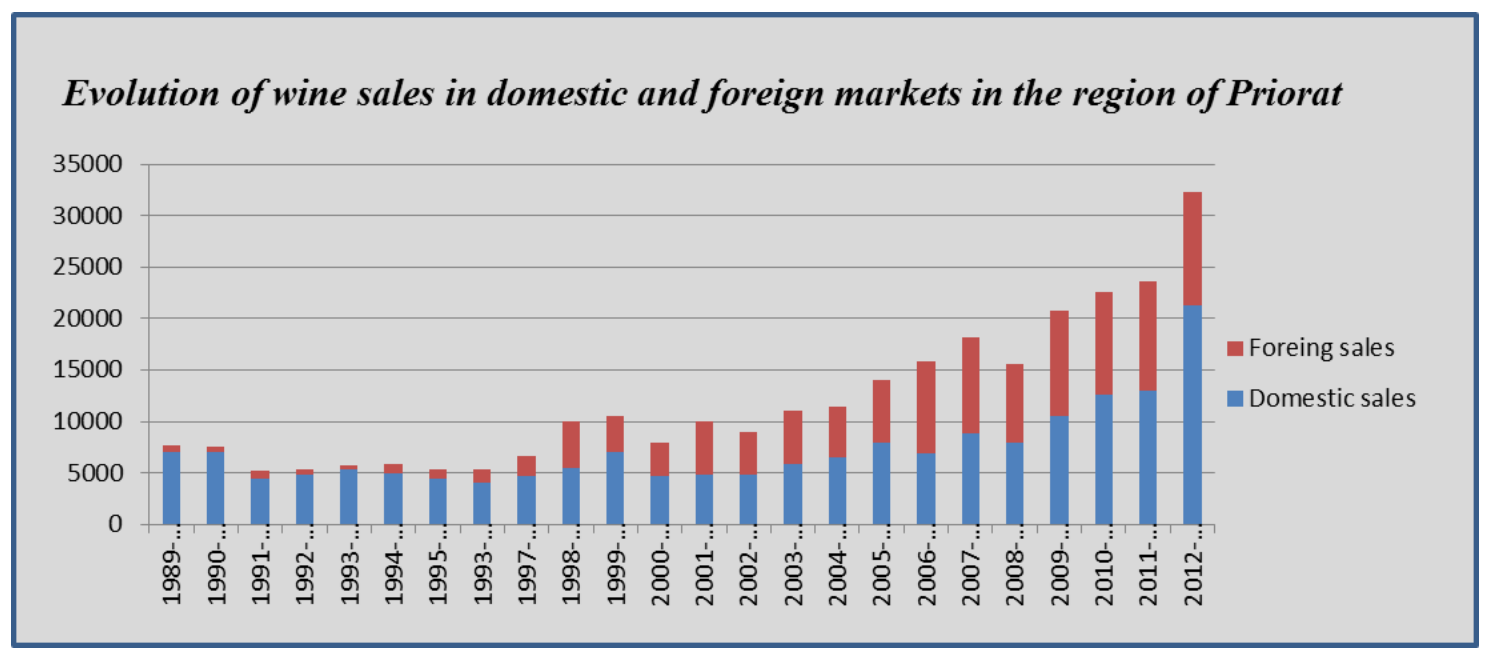

Source: Authors calculations based on statistics provided by Generalitat de Catalunya, DOQ Priorat Council, and DO Montsant Council $^{\mathrm{x}}$.

Convinced of the possibility of a successful alliance, he took the floor. Everyone looked at each other in silence and finally Christopher communicated and discussed the content of the proposal. 
After sharing his plan with the entire group, he broke protocol and uncorked a special bottle that he kept hidden and all toasted with full glasses. After the first sip, everyone understood that everything was ready. The project of the Magnificent Five began to roll.

iii ibid.

iv Atkin, T. (2014). How hippies and dreamers transformed Priorat into a success story. Wine Searcher. Retrieved from: http://www.wine-searcher.com/m/2014/09/how-hippies-and-dreamers-transformed-priorat-into-a-success-story.

${ }^{\vee}$ Personal communication with winemakers, 2014.

vi Bou, E., Sauquet, A., \& Canestrino, R. (2008, July). Collective networks and communities of practice: The transformation of the Priorat wine region. Paper presented at the 4th International Conference of the Academy of Wine Business Research, Siena, Italy.

vii Wine Searcher. (2016). Priorat wine region. Retrieved from http://www.wine-searcher.com/regions-priorat

viii Best Spanish Wines (2017). Robert Parker's 100 point Best Spanish Wines 2010 - Best Wines from Spain. Retrieved from http://www.bestspanishwines.com/robertparker2010.php;

Catalunya Wine. (2014). Clos i Terrasses Daphne Glorian and revelations of a nervous interviewer. Retrieved from http://catalunyawine.com/clos-i-terrasses-daphne-glorian-and-revelations-of-a-nervous-interviewer/;

USDA Foreign Agricultural Service. (2016). 2015 annual report of Spanish wine exports. Retrieved from https:/gain.fas.usda.gov/Recent\%20GAIN\%20Publications/2015\%20was\%20a\%20record\%20year\%20for\%20Span ish\%20wine\%20exports_Madrid_Spain_4-1-2016.pdf.

ix Departament d’Agricultura, Ramaderia, Pesca i Alimentació. Generalitat de Catalunya. (2017). Comerç Internacional de Catalunya. Retrieved from http://agricultura.gencat.cat/ca/departament/dar estadistiques observatoris/dar comerc internacional/;

DOQ Priorat Council. (2017). Informe Collita. Retrieved from http://www.doqpriorat.org/en/butlletins;

DO Montsant Council. (2017). Dossier Montsant. Retrieved from http://www.domontsant.com/sites/default/files/Dossier\%20Montsant\%20(ENG) 0.pdf.

${ }^{x}$ ibid. 